\title{
Understanding Basics of Wheat Grain and Flour Quality
}

\author{
Melaku Tafese Awulachew \\ Department of Food Science and Nutrition Research Process, Ethiopian Institute of Agricultural Research, Kulumsa Agricultural Research \\ Center, Assela, Ethiopia
}

Email address:

Melakutafese12@gmail.com

To cite this article:

Melaku Tafese Awulachew. Understanding Basics of Wheat Grain and Flour Quality. Journal of Health and Environmental Research. Vol. 6, No. 1, 2020, pp. 10-26. doi: 10.11648/j.jher.20200601.12

Received: August 19, 2019; Accepted: October 25, 2019; Published: April 8, 2020

\begin{abstract}
The aim of this material was to assist farmers, traders, processors and certified graders to understand and apply the wheat grains quality standard correctly in the determination of wheat quality and to ensuring that wheat farmers, traders, grain handlers, and processors meet relevant standards, reduce post-harvest wastage and provide safe, appropriate quality Wheat to consumers. This publication provides an insight into grain and flour quality wheat. In order for Ethiopian wheat to be marketable both domestically and for export, it must be suitable for its intended end-uses. This material provides information on the quality attributes for grain and flour quality. There is a continuing need for wheat quality research to maintain existing standards, to introduce new and updated information and to identify novel traits, markets and end-use products. All this information must be available to wheat breeders so that new wheat varieties target the intended end-use of growers, marketers and consumers. While farm-gate return in birrs per hectare will always be a grower's key focus, choosing the variety that suits local growing conditions and is attractive to a range of buyers should help achieve maximum financial return. Considering the fact that the quality standards of wheat have been a major issue throughout the globe. Several recent timely topics have directed readers to information on Wheat and wheat quality standards. The Quality of wheat flour greatly affects water absorption, dough mixing requirements, proof times, yield and quality, mainly in terms of textural shelf life. These characteristics, plus the ability to absorb large quantities of sauce without becoming sticky, combine to give the required mouth feel. Therefore these basics will give you an edge in understanding how wheat and flour quality influences end use products. Wheat traders, marketers, plant breeders, bakers, growers, administration, sales personnel, managers - anyone working in the grains industry who would benefit from understanding this materials about grain and flour quality of wheat.
\end{abstract}

Keywords: Quality Standards, Grain, Flour, Wheat

\section{Introduction}

Wheat (Triticum aestivum L.) is the most important cereal crop and staple food of about two billion people around the world [1]. This publication has been prepared to provide an introduction to Ethiopian wheat Grain and flour quality. It is intended to be of interest to a wide range of audiences including those new to the wheat industry and those involved at various points in the wheat value chain, who need or wish to better understand the fundamental aspects of wheat quality. In order for Ethiopian wheat to be marketable both domestically and for export, it must be suitable for its intended end-uses. This publication provides information on the quality attributes that are important to achieving this goal. There is a continuing need for wheat quality research to maintain existing standards, to introduce new and updated information and to identify novel traits, markets and end-use products. All this information must be available to wheat breeders so that new wheat varieties target the intended enduse of growers, marketers and consumers.

I particularly keen that the publication is of value to growers as it will help to explain the quality factors inherent in the genetic composition of a variety, and those that are influenced by the environment. While farm-gate return in birr's per hectare will always be a grower's key focus, choosing the variety that suits local growing conditions and is attractive to a range of buyers should help achieve maximum financial return. This publication provides an insight into what factors are required to achieve a highquality grade at the silo or the mill. And also, it assists farmers, traders, processors and certified graders to 
understand and apply the ES 665: 2017 wheat grains quality standard correctly in the determination of wheat quality. Ensuring that wheat farmers, traders, grain handlers, and processors meet relevant standards, reduce post-harvest wastage and provide safe, appropriate quality Wheat to consumers [2]. The objective of this publication was to explain and demonstrate to farmers, traders and dealers that the quality of wheat is measurable and also to acquaint the farmers and traders with the common physical defects in wheat that can hinder market access and profitability, demonstrate how physical defects were assessed in meeting standards requirements.

\section{Materials and Methods}

\subsection{Basis of the Document}

The kernel of wheat is composed of the outer bran layer, the germ, and the endosperm. It is rich in nutrients, many of which are concentrated in the bran and germ. Of special importance is that it contains the entire B complex, except for vitamin B12. B vitamins function as cofactors in many metabolic reactions involved in the release of energy [3]. This material for anyone working with wheat farmers, traders, grain handlers and grain processors; outlined grading based on the quality of wheat grain specifications. The document can be adapted to train various groups with different interests; farmers of production and delivery of quality crop; traders, grain handlers and processors, on grading delivered wheat.

\subsection{World and Ethiopia Wheat Production}

Wheat (Triticum aestivum L.) is one of the important grain crops produced worldwide. Commercially cultivated wheat is basically of two types, i.e. durum wheat (Triticum turgidum) and bread wheat (Triticum aestivum), which differ in their genetic makeup, adaptation and uses. According to the FAO, 2005 report, about 620 million metric tons of wheat was produced from 217 million hectares in the year 2005/06 with an average yield of 2.85 metric tons per hectare [4]. Wheat is grown on larger area than any other crop and its world trade is greater than for all other crops combined. Its world trade is greater than for all other crops combined. It is easily stored and transported [5].

In terms of production and consumption, wheat is one of the main cereals grown in Ethiopia also as it is produced by about 4.6 million farmers producing close to 4.2 million tons that cover 1.6 million hectares of land per annum [6]. According to the same source, the average productivity of wheat in the country has been consistently increasing for the last 20 years and has reached about $2.5 \mathrm{t} / \mathrm{ha}$. This was due to the efforts done in the use of recommended inputs like fertilizer, improved varieties and cultural practices (which the results of the national agricultural research system). However, the increase in the total production in the recent years has been somewhat slow mainly because of rust epidemics. This contributed to the wheat production lag behind consumption making the country to be net importer and the volume of annual imports is increasing over the years. In order to curve a trend the government is working to increase rapidly the total production to achieve selfsufficiency. Availability of high yielding and disease resistant wheat varieties with competent nutritional and processing quality is one of the critical factors that can contribute to the effort. Therefore, the national agricultural research system is working to address issue and so has released a number of improve varieties. Recently, in addition to the focus for high yield, the national wheat research program is being pressured to revise its priority and to focus on quality-oriented breeding. Wheat quality depends upon the genetic factors but, environmental conditions, growth locations; agronomic practices prevailing during different wheat growth stages greatly alter the wheat end-use quality attributes [7]. Wheat ranks in Ethiopia fourth after Teff (Eragrostis tef), Maize (Zea mays) and Sorghum (Sorghum bicolor) in area coverage and third in total production [8]. The average per capital consumption of wheat in Ethiopia estimated to be $39 \mathrm{~kg} /$ year during 1994-97 and 331,000 tons of wheat imported to meet the national wheat requirements during 1995-97 [9]. The national average yield of wheat in the country, which is 1.379 tons ha- 1 , is $24 \%$ and $48 \%$ below the African and world average, respectively [10]. In Ethiopia, it is largely grown in the highlands of the country and constitutes roughly $10 \%$ of the annual cereal production and plays an appreciable role in supplying the population with carbohydrates, protein and minerals [11]. The crop is grown at an altitude ranging from 1500 to 3000 meters above sea level (masl), between 6-160 $\mathrm{N}$ latitude and $35420 \mathrm{E}$ longitude. The most suitable agroecological zones, however, fall between 1900 and 2700 masl [12]. The major wheat producing areas in Ethiopia are located in Arsi, Bale, Shewa, Ilubabor, Western Hareghe, Sidamo, Tigray, Northern Gonder and Gojam zones [12].

\subsection{Fundamentals of Wheat Quality}

\subsubsection{Wheat Value Chain}

Value chain: Kaplinsky and Morris defines the value chain as "the full range of activities which are required to bring a product or service from conception, through the intermediary phases of production, delivery to final consumers, and final disposal after use [13]. "A value chain consists of all valuegenerating activities, sequential or otherwise, required to produce, deliver and dispose of a commodity [14]. The value chain concept entails the addition of value as the product progresses from input suppliers to producers and consumers. A value chain, therefore, incorporates productive transformation and value addition at each stage of the value chain. At each stage in the value chain, the product changes hands through chain actors, transaction costs are incurred, and generally, some form of value is added. Value addition results from diverse activities including bulking, cleaning, grading, and packaging, transporting, storing and processing [15].

Supply chain: It is an integrated process where a number of various business entities (i.e. suppliers, manufactures, distributors, and retailers) work together in an effort to 
acquire raw materials, convert these materials into specified final products, and deliver these final products to retailers. The chain is traditionally characterized by a forward flow of materials [16]. It is a set of linkages between actors where there are no binding or sought-after formal or informal relationships, except when the goods, services and financial agreements are actually transacted [17]. A supply chain is the portion of the value chain that focuses primarily on the physical movement of goods and materials, and supporting flows of information and financial transactions through the supply, production, and distribution processes. Many organizations use the terms "value chain" and "supply chain" interchangeably. A value chain is broader in 8 scopes than a supply chain, and encompasses all pre- and post- production services to create and deliver the entire customer benefit package. A value chain views an organization from the customer's perspective; the integration of goods and services to create value while a supply chain is more internally focused on the creation of physical goods. The supply chain focus is on understanding the impact of tightly coupling supply chain partners to integrate information, physical material, product flow, and financial activities to increase sales, reduce costs, increase cash flow, and provide the right product at the right time and at the right price to customers [18].

Value chain actors: They are those involved in supplying inputs, producing, processing, marketing, and consuming agricultural products [18]. According to GTZ, the term "value chain actors" summarizes all individuals, enterprises and public agencies related to a value chain, in particular the value chain operators, providers of operational services and the providers of support services [19]. In a wider sense, certain government agencies at the macro level can also be seen as value chain actors if they perform crucial functions in the business environment of the value chain in question. Value addition: is simply the act of adding value to a product, whether you have grown the initial product or not. It involves taking any product from one level to the next [20]. It refers to increasing the customer value offered by a product or service. It is an innovation that enhances or improves (in the opinion of the consumer) an existing product or introduces new products or new product uses. Adding value does not necessarily involve altering a product; it can be the adoption of new production or handling methods that increase a farmer's capacity and reliability in meeting market demand. For farmers, value addition has a particular importance in that it offers a strategy for transforming an unprofitable enterprise into a profitable one. The farmer is not only involved in production of a raw commodity but also takes part in value addition and distribution. This allows the farmer to create new markets or differentiate a product from others and thus gain advantage over competitors. Value-added is determined by the difference between the cost of the inputs and outputs at each stage of the chain [21]. Value-addition can involve different activities: change in the physical state or form of the Product (such as milling wheat into flour; or making strawberries into jam), production of a 9 Product in a manner that enhances its value, as demonstrated through a business plan (such as organically produced products); physical segregation of an agricultural commodity or product in a manner that results in the enhancement of the value of that commodity or product (such as an identity preserved marketing system which creates a special link/ between the grower and consumer by meeting the specific requirements of food processors) [21].

Market: is an area in which one or more sellers of given products/services and their close substitutes exchange with and compete for the patronage of a group of buyers. Originally the term market stood for the place where buyers and sellers are gathered to exchange their goods, such as village square. A market is a point, or a place or sphere within which price making force operates and in which exchanges of title tend to be accompanied by the actual movement of the goods affected [22]. The concept of exchange and relationships lead to the concept of market. It is the set of the actual and potential buyers of a product [23].

Marketing: The definition of marketing as a process by which individuals and groups obtain what they need and want by creating and exchange products and values with others involves work. Marketing means different things to different people: to the house wife it means shopping for food; to the farmer it means the sale of his produce; to the fertilizer distributor it means the selling to the farmer [24]. According to Kotler, P. and Armstrong, G. marketing is managing markets to bring about profitable exchange relationships by creating value and satisfying needs and wants [23]. Market chain: It is the term used to describe the various links that connect all the actors and transactions involved in the movement of agricultural goods from the producer to the consumer [25].

Marketable surplus: It is the quantity of produce left out after meeting farmer's consumption and utilization requirements for kind payments and other obligations (gifts, donation, charity, etc) [26]. Marketed surplus: It shows quantity actually sold after accounting for losses and retention by farmers, if any and adding previous stock left out for sales. Thus, marketed surplus may be 10 equal to marketable surplus, it may be less if the entire marketable surplus is not sold out and farmers retain some stock and if losses are incurred at the farm or during transit [26].

Marketing channel: is the set of interdependence organization that ease the transfer of ownership as products move from producer to consumer. Usually marketing follows a fairly well established channel from producers to consumers. This channel may be short or long depending on kind and quality of the product marketed, available marketing services, and prevailing social and physical environment [27].

The wheat value chain is shown in Figure 1. The driving factor is the relationship between all involved, and the need for each level in the value chain to respond to the needs of others while being able to extract value in a commercial environment. Ultimately, the value chain is consumer driven. Wheat quality is complex and has different meanings at each 
step of the value chain. To some, quality merely equates to price; to others, it is the complexity of the genetics and processing systems used to produce the diverse range of flours needed to manufacture the seemingly endless array of end products demanded by consumers. At its most basic level for processing into end products, wheat quality can be broken down into a few fundamental components. Not surprisingly, these components are the basis for world wheat trade and the grading systems countries use to provide grain to the trade. Three factors - grain hardness, grain protein content and dough or protein quality aspects - explain most of the variation in wheat quality. Generally, the concept of value chain provides a useful framework to understand the production, transformation and distribution of a commodity or group of commodities. With its emphasis on the coordination of the various stages of a value chain, value chain analysis attempts to unravel the organization and performance of a commodity system. The issues of coordination are especially important in agricultural value chains, where coordination is affected by several factors that may influence product characteristics, especially quality [15].

\section{Consumer $\leftrightarrow$ Retailer $\leftrightarrow$ Distributor $\leftrightarrow$ Food product manufacturers $\longleftrightarrow$ Millers $\rightarrow$ Marketers}

\section{Storage, Handling \& Transport}

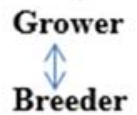

Figure 1. The consumer driven wheat value chain.

\subsubsection{Quality Fundamentals}

The role of genetics and the environment One of the aspects contributing to the complexity of wheat quality is that its expression as measured through a range of analytical tests is the result of genetics, the growing season environment and the interaction between the two, known as genotype $x$ environment $(G \times x)$ interaction. The priority has now gradually shifted to the improvement of processing quality, due primarily to the increase in food diversity and market demand $[28,29]$. Consequently, improving wheat grain protein content (GPC) and processing quality has become one of the main breeding goals [29-31]. However, our knowledge of this aspect is still limited; thus, programs for this aim are hampered mainly by an unawareness of the strong influence of environment on grain quality ( $\mathrm{Li}$ et al., 1995). Numerous studies have been carried out to evaluate the effects of environmental diversity on wheat quality. This research has environment, genotype, and genotype by environment $(\mathrm{G} \times \mathrm{E})$ interactions on quality traits is likely to become a crucial issue [30-33]. Additionally, a directory that includes the regularization of wheat production area with wellcharacterized production environments could be used to plant wheat cultivars with targeted end-uses. Proteins are the most important component of wheat grains governing the technological and rheological properties of flour and are closely associated with end-use quality [34]. GPC, particularly glutenin content, is positively correlated with Zeleny sedimentation value (SV), and stability time (ST) and is thus regarded as an important index for wheat quality [35, 36].

These effects on wheat quality are summarized in Table 1.

Table 1. The effects of genetics, environment and /or both factors on wheat quality.

\begin{tabular}{lll}
\hline Genetics (G) & Environment (E) & G x E interaction \\
\hline Protein quality, dough strength and stability & Grain protein content & Grain protein content \\
Grain hardness & Grain plumpness and test weight & Screenings levels \\
Milling yield & Weather damage effects (like frost and sprouting) & Test weight \\
Pre-harvest sprouting tolerance due to dormancy & Grain moisture content & \\
\hline
\end{tabular}

\section{i. Protein Content}

Protein content is important as it is one of the key criteria on which international wheat trade is based. Buyers use protein content as an indication of the potential end-uses of a parcel of wheat. Wheat breeding and variety classification are both critical in maintaining the linkage between protein content and end-use quality so that buyer's expectations are fulfilled. Buyers also use protein content to indicate suitability for most end-uses. It is the protein component in flour that, when hydrated by the addition of water and mixed and or kneaded, forms a continuous network of gluten. It is the gluten network that provides the cell structure to a loaf of bread. The quality of the gluten can have a substantial effect on bread loaf volume, appearance and consumer acceptance. Similarly, gluten provides the structure to sheets and strands of noodles with the level of protein in the flour having a pronounced effect on the texture or mouth-feel of cooked noodles. There is an optimum range of protein content for most end-uses of Australian wheat.

ii. Protein Quality

The quality of wheat protein is a more difficult concept than that of protein content as it includes the proteins involved in the formation of gluten and the properties of gluten. The first classification of wheat proteins was according to their solubility. Albumins were water soluble, globulins were salt soluble, gliadins alcohol soluble and the 
glutenins were divided into acid soluble and acid insoluble fractions. The total acid insoluble fraction of glutenin contributes significantly to dough strength and baking quality and the gliadin fraction to dough extensibility. Today endusers apply a range of measurements, from the determination of the actual amount of gluten in flour, through to the assessment of the viscoelastic properties of a dough. Irrespective of what is measured, inevitably protein quality is related to dough functionality and the suitability of flour for end-product processing. A suitable balance of acid insoluble glutenin and gliadin, in combination with a particular level of total protein, is needed for most flour end-uses.

\subsubsection{The Concept of Protein Content Versus Protein Quality}

Grain protein content in the mature grain is largely determined by environmental and farm management factors, with genetics playing a minor role in being either low or high in protein content. By contrast, protein quality is determined by the genetic composition of the wheat variety and also how the environment influences genetic expression. It is always important to be clear about whether it is protein content or protein quality that is being considered.

\subsection{Grading Systems (Concept of Grading)}

Grading is a means of segregating wheat exhibiting different attributes such as grain hardness, grain colour, protein content and the different dough strengths needed for various end products. Grading is also used by grain buyers and traders to separate sound wheat, suitable for human consumption, from weather damaged and disease or droughtaffected grain of lesser value. Traditionally, when small distinct parcels of grain were traded, grading was limited to the visual appearance and smell of the grain (to identify weather effects), the presence of diseased grain, other contaminants, and the extent of the inevitable insect infestation. As grain trading became more sophisticated, buyers demanded to know more about the grain they were purchasing. This resulted in the use of the bushel measure, which is the weight of grain that would fill a container of 8 imperial gallons. This type of measure, now metricated to hectoliter weight (weight of 100 litres of grain), is referred to as test weight and is still regarded as a reliable indicator of overall wheat quality. It reflects the growing conditions and stresses that the wheat plant has endured during its development, including drought, leaf, stem and root diseases, frost, heat stress, and rain during grain filling, maturation and the immediate pre-harvest period. Modern grading systems satisfy a number of key criteria. First, they must have commercial relevance and clearly reflect the value of the grain to the end-user. In the case of wheat, this requires the application of standards which exclude deleterious factors such as sprout damage and contamination with noxious weed seeds and include standards for physical characteristics, milling performance, protein content and water absorbing capacity of dough. These standards indicate the suitability of the grain for the production of flour for particular end-uses.
Second, any grading system must be simple to apply at all grain receival points, using rapid, reproducible and robust testing methods. Third, and most important, the standards being applied must be readily achievable by farmers in their production regions in order to meet the first criterion of commercial relevance of the grain to potential end-users.

\subsection{Breeding for Wheat Quality}

\subsubsection{Defining Breeding Targets}

A good wheat variety must meet the needs of all in the wheat value chain. That is, from the farmer, to the miller, to processors and manufacturers through to the consumer. Wheat breeders need to understand the needs of all in the value chain and use the available genetics and quality testing capability to develop new varieties that will produce the high quality, attractive and nutritious bread, cake and pastry products demanded by consumers. Successful wheat breeding is about having clearly defined and achievable targets. Agronomic attributes like plant height, straw strength, ease of threshing and maturity optimum for the target production region are essential components of all varieties. A thorough knowledge of the environment of the target production region is critical, as this determines yield potential, the range and type of challenges the crop will experience from biological threats such as pests and diseases and soil and environmental stresses. Importantly, it also determines the quality type that can be reliably and profitably grown in that region. Rainfall sets yield potential and along with the onset of summer temperatures determines the quality types that can be reliably and profitably grown. Other major environmental influences effecting yield potential and quality are soil type, high temperature events during grain development and the occurrence of frost events during vegetative growth and or at flowering time. The interplay between rainfall distribution and temperature, in the presence of susceptible varieties, creates the conditions for disease epidemics, and Ethiopian breeders have to contend with a formidable list of diseases including, stem, leaf and stripe rust, yellow spot, septoria tritici blotch, septoria nodorum blotch, crown rot, take-all, common root rot, and 3 different soil-borne nematodes. Most diseases have an adverse impact on grain, processing and end-product quality.

\subsubsection{Setting Quality Targets}

Determining the quality target for a breeding program requires a thorough knowledge of the production region and its environment, but also an understanding of the requirements of others in the value chain who will buy, process and manufacture the wheat into end products. With the target production region, quality type and how that grain will be utilized defined, it is now possible to start assembling the germplasm (the collection of genes available to wheat breeders) required to commence a breeding program. For the breeding program to be successful quality wise, the breeder needs to work with a cereal chemist who manages a laboratory that has all the equipment needed to screen breeding lines at the different stages of their development in 
the breeding process. Deployment of quality testing needs to be done so that the fundamental components of quality are always assessed. These fundamentals are grain hardness or texture, the amount of protein (grain or flour protein content) and protein quality. Each has a major influence on how well any wheat will make end products, the ultimate assessment of wheat quality. Each fundamental is a measure in its own right, but each also has major influences over other properties measured using other tests. The relationship between these 3 basic parameters was visualized [37]. Grain hardness, or endosperm texture influences how the grain will perform during milling, with hard wheat suffering greater starch damage, resulting in their flours having higher water absorption. Soft wheat, on the other hand experience less starch damage and have lower water absorptions. Grain and flour protein content also indicate potential water absorption, dough strength and extensibility. Extensibility generally increases with protein content and it is desirable for dough strength to respond in this way as well. When combined with protein quality measures they all indicate the potential of a dough to perform under the stresses of dough mixing and the manufacture of end products. Breeders handle thousands of lines per year and they need to be whittled down to the few lines that may end up as varieties. Consequently, a tiered quality evaluation system is used. In the first stages of testing, where $1,000 \mathrm{~s}$ of lines may be under evaluation, simple, rapid and cheap tests with a high daily throughput and predictive capacity are required. Breeding programs are major users of Near Infrared Reflectance (NIR) and Near Infrared Transmittance (NIT) instruments for determining important attributes like grain and flour protein content and grain hardness. In the next stages of selection and evaluation, the mid- and late stages, where 100s and then 10s of lines are under evaluation, higher levels of sophistication are employed. This sees the use of milling procedures that more closely simulate what happens in a commercial flour mill, combined with the use of dough rheology testing (dough mixing and stretching characteristics) using laboratory instruments like the Mixograph, Farinograph, Extensograph and Alveograph. Testing of end products usually commences with a pan bread style test bake, using about $100 \mathrm{~g}$ of flour to assess loaf volume potential, crust colour and crumb appearance and softness. At the final stages of testing extensive production of end products such as a range of pan bread styles, steamed and flatbreads, different types of noodle and biscuits are evaluated. Examples of the types of tests deployed at each stage of a typical breeding program are summarized in Table 2.

Table 2. The types of quality tests deployed by wheat breeders at each stage of testing

\begin{tabular}{|c|c|c|c|c|}
\hline & Hardness & Protein content & Protein quality & End products \\
\hline $\begin{array}{l}\text { Early stage } \\
\text { testing }\end{array}$ & Grinding tests NIR/NIT Micro-milling & $\begin{array}{l}\text { Dumas/ Kjeldahl } \\
\text { NIR/NIT }\end{array}$ & $\begin{array}{l}\text { DS volume Zeleny volume } \\
\text { Pelshenke time }\end{array}$ & No end product testing \\
\hline $\begin{array}{l}\text { Mid stage } \\
\text { testing }\end{array}$ & $\begin{array}{l}\text { NIR/NIT Milling quality (Quadrumat or } \\
\text { Buhler yiel d and flour colour) }\end{array}$ & $\begin{array}{l}\text { Dumas/ Kjeldahl } \\
\text { NIR/NIT }\end{array}$ & $\begin{array}{l}\text { Mixograph Farinograph } \\
\text { Extensograph }\end{array}$ & $\begin{array}{l}\text { Test bake (pan bread style) Noodle } \\
\text { sheet colour development and stability }\end{array}$ \\
\hline $\begin{array}{l}\text { Late stage } \\
\text { testing }\end{array}$ & $\begin{array}{l}\text { NIR/NIT Bühler milling (yield and flour } \\
\text { colour) Ash \% Colour grade Starch damage }\end{array}$ & $\begin{array}{l}\text { Dumas/ Kjeldahl } \\
\text { NIR/NIT }\end{array}$ & $\begin{array}{l}\text { Farinograph Extensograph } \\
\text { Alveograph }\end{array}$ & $\begin{array}{l}\text { Test bake (pan, steamed and flatbread } \\
\text { styles) Noodle colour and texture }\end{array}$ \\
\hline
\end{tabular}

\section{Discussion}

\subsection{Uses of Wheat (Triticum spp.)}

Cereal grain, originally from the Levant region of the Near East but now cultivated worldwide. Third most produced crop globally after maize and rice and the Staple food used to make flour bread (leavened, flat and steamed), biscuits, cookies, cakes, breakfast cereal, pasta, noodles, and couscous and for fermentation to make beer, other alcoholic beverages, or bio fuel. Milled to leave just the endosperm for white flour. By-products are bran and germ. Whole grain is a concentrated source of vitamins, minerals, and protein, while the refined grain is mostly starch.

\subsubsection{Common Wheat (Triticum aestivum L.)}

Also known as bread wheat; Well adapted to modern industrial baking; Can be hard or soft wheat, depending on grain hardness; Utilized mainly as flour (whole grain or refined) for the production of a large variety of leavened and flat breads, and for the manufacture of a wide variety of other baking products.

\subsubsection{Club Wheat (Triticum compactum Host.)}

Composes a subclass of soft white wheat; Has less potential for gluten strength/elasticity or dough water absorption; Suited to production of cookies/biscuits, requiring less bake-out and producing a more tender product; Best used for cake-baking, especially Japanese sponge cake production, where cake volumes are greater than those of soft white wheat, which also produce excellent cakes.

\subsubsection{Durum (Triticum durum Desf.)}

Latin means "hard", and the species is the hardest of all wheat's with High protein content, as well as its strength, makes durum good for special uses, production of semolina (coarse flour), and the main raw material of pasta making. Used extensively in bread-making; despite very high protein content, it is low in desirable gluten needed to form a glutinous web necessary for bread to rise. Sole durum flour in bread: need substantial additions of isolated wheat gluten to effect rising. Hundred percent durum wheat breads are often heavy, with very close grain, and will split easily when raised for baking.

Those differences between durum and common wheat were illustrated in the figure 2 , below. 


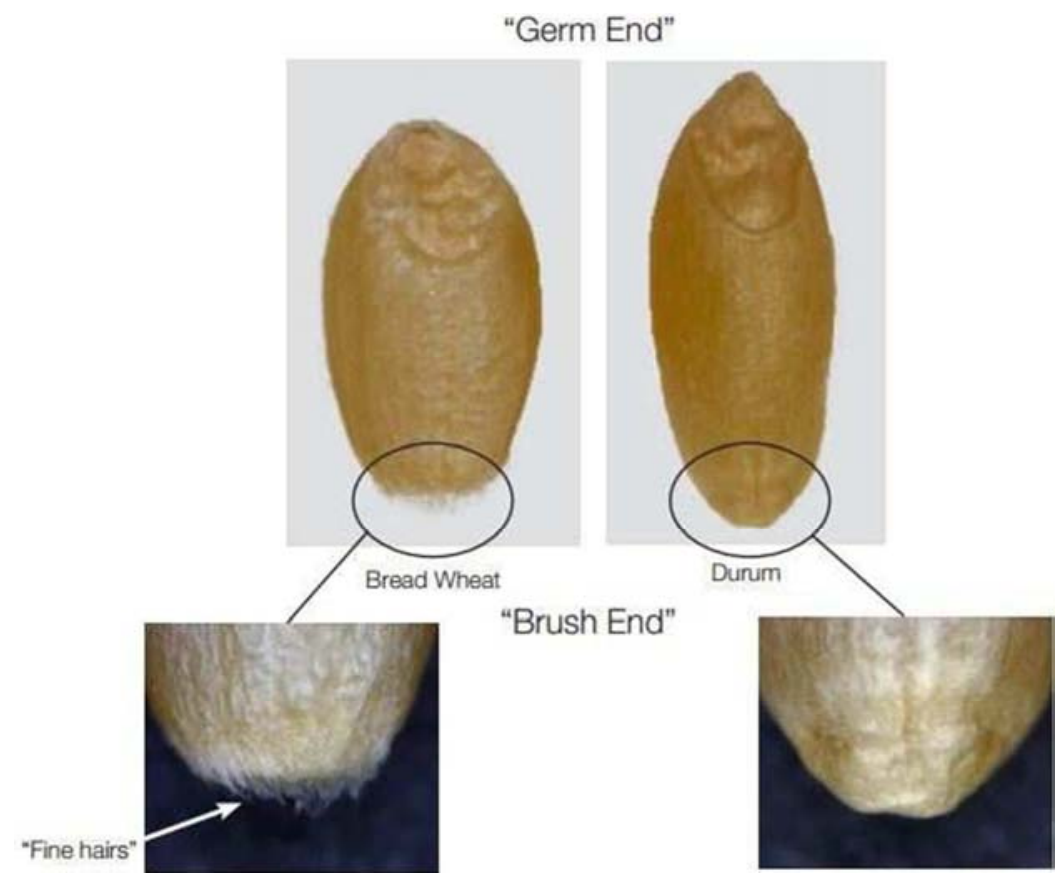

Figure 2. Difference between durum and common wheat.

\subsection{Grain Quality and Grain Quality Standards}

\subsubsection{Overview}

Proper use of the ES 665: 2017 wheat grain specifications quality standard. Farmers should know that wheat quality assurance involves prevention of defects from the earliest stages of cultivation including proper land preparation and using the right inputs; Standards only help to assess the quality of the harvested crop.

"Quality" as applied to food material refers to those attributes of the food which make it agreeable to those who consume it. Attributes of quality involve color, flavor, texture, nutritional value and the absence of harmful substances such as microorganisms, insects, pest and their metabolic products, chemical residue and noxious seeds. Grain quality is generally assessed based on general aspects (characteristics that give value to the user) For example: Broken grains, low test weight and high moisture grain reduce the amount and/or quality of flour a miller gets after milling; Safety aspects (characteristics that pose a hazard to the end user). E.g. Toxic seeds and pesticide residue could harm the consumer; any grain that does not meet safety requirements is rejected despite looking physically appealing or meeting the general quality characteristics. Grain quality may have different meanings to different people and may depend on the grain type and its end use; Requirements of: Farmers; Traders; Millers and Consumers are not necessarily compatible; Quality Standards have to be established to even the playing field.

\subsubsection{Quality Standards}

Measures that serve as a basis for making comparisons or judging the accuracy of unknown samples;

Established for a variety of purposes including facilitating smooth and fair trading and protection of consumers; An example of a quality standard is: "ES 665: 2017 Wheat grains - specification" which was developed in order to harmonize wheat quality requirements in Ethiopia developed by national, regional and international standards institutions often to enforce legislation; specifications for commodities as well as methods of testing. Examples of these bodies include: Ethiopian standard agency (ESA); East African Community (EAC); American Association of Cereal Chemists (AACC); Association of Analytical Chemists (AOAC) and; International Standards Organization (ISO). It is common for standards bodies to adopt standards issued by another body. For example: ES 665: 2017 (Wheat grains specifications) has adopted ISO 605 test methods to determine foreign matter. All adopted Standards appear under "normative references". When testing under a particular standard, all the standards referred to under "Normative references" have to be followed as well.

\subsubsection{Quality Control}

Quality control: A system of maintaining standards in products by testing a sample to see if it meets the required standards; Involves use of a particular standard, test method and equipment to detect defects and assess the quantity of certain physical, sanitary or chemical quality parameters.

Grain grading: A process of categorizing grain based on certain quality parameters; informs decisions such as storage of the grain, uses of the grain, the purchase price and so on.

\subsubsection{Wheat Grain Quality Standards}

Based on "ES 665: 2017 Wheat grain specifications"; a wheat standard passed by EAC and adopted by partner states for implementation in their respective countries; Standard defines Wheat as grain that consists of $50 \%$ or more common wheat (Triticum aestivum L.), club wheat (Triticum compactum Host.), and durum wheat (Triticum durum Dest.). Wheat varieties are called "soft" or "weak" if gluten content is low, and are called 
"hard" or "strong" if they have high gluten content. Those the hard or soft wheat type were illustrated in figure 3.

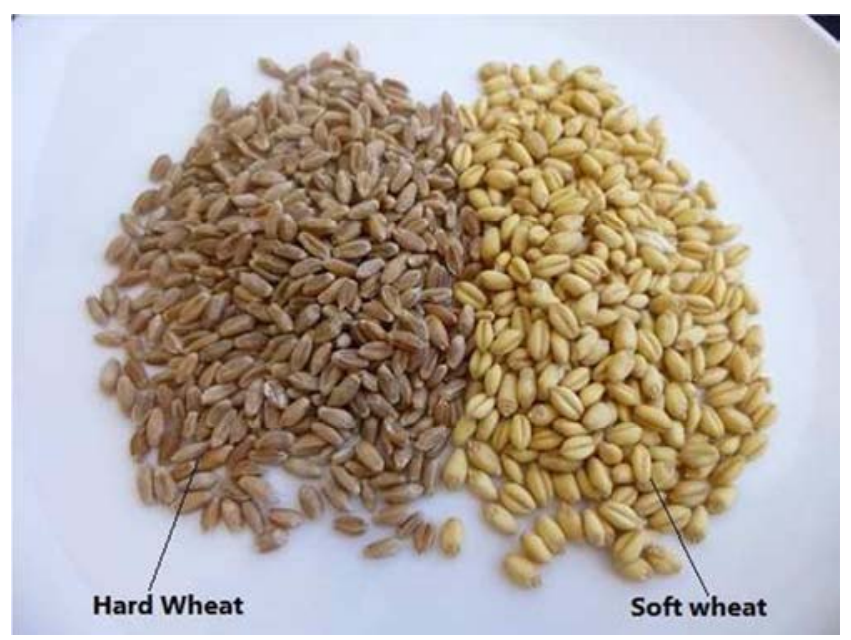

Figure 3. Hard and soft wheat.

\section{i. Color}

Wheat comes in different colors: red, white, and amber were illustrated in figure 4 .

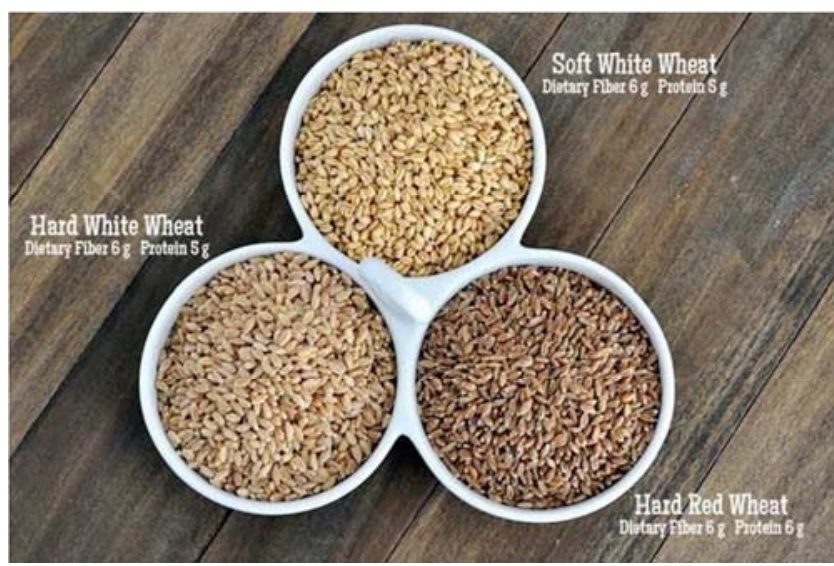

Figure 4. White and red wheat.

ii. Test weight

Test weight, also called, "bulk density", "bushel weight" or "standard of quality" in ES 665: 2017;

Is the weight per unit volume of wheat (grain density); It can be expressed as kilograms per hectoliter or grams per liter; High test weight grain tends to yield more flour.

\subsubsection{Grain Defects}

i. Broken Grains

Pieces of wheat kernels that pass through a $1.6 \mathrm{~mm}$ wide, $9.5 \mathrm{~mm}$ long slotted sieve.

\section{ii. Foreign Matter}

Organic and inorganic material other than wheat, broken kernels, other grains and filth; Organic matter is material of plant origin e.g. stalks, chaff, weed seeds, etc. and also, inorganic matter includes plastics, stones, glass, metals, etc. Hence the organic and inorganic foreign matters were given in figures 5 and 6.

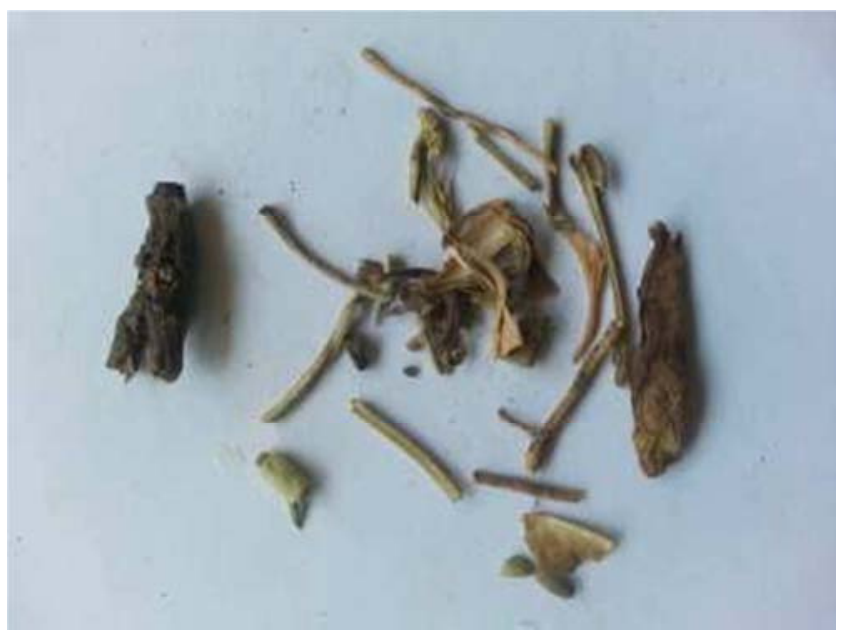

Figure 5. Organic.

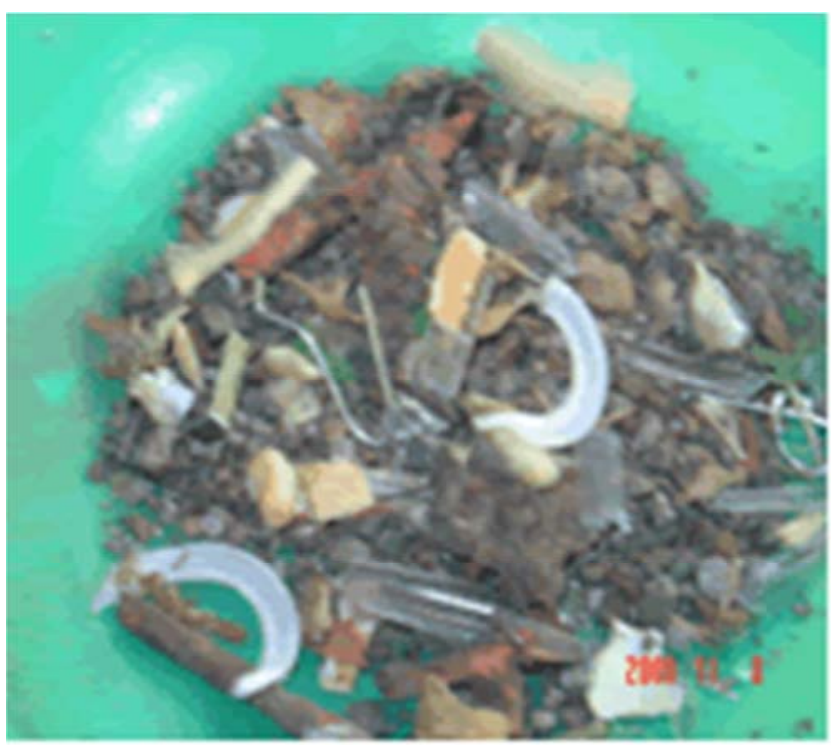

Figure 6. Inorganic matter.

\section{iii. Discolored Grain}

Wheat kernels that are discolored by heat, fermentation, moulds, weather or disease but do not include black point which is brown, dark brown or almost black discoloration at the end embryo end of the grain and this was shown in figures 7 and 8 .

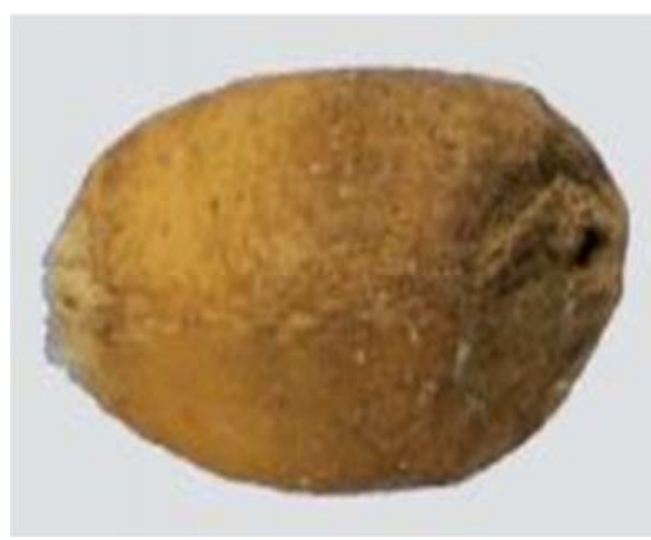

Figure 7. Discolored. 


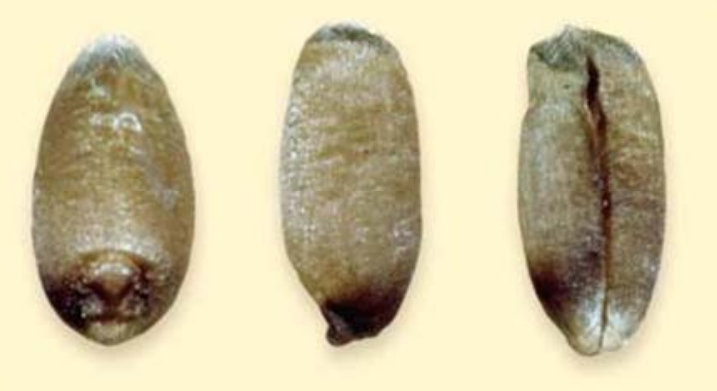

Figure 8. Black-tipped (not discolored).

iv. Pest Damaged Grain

Wheat kernels damaged by insects or other pests were given under figure 9.

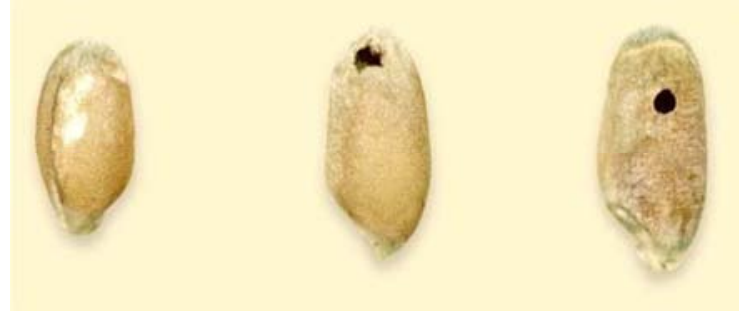

Figure 9. Pest damaged grain.

\section{v. Infested Grains}

Wheat containing any form of living organisms capable of causing damage or spoilage to wheat kernels and given in figure 10 .

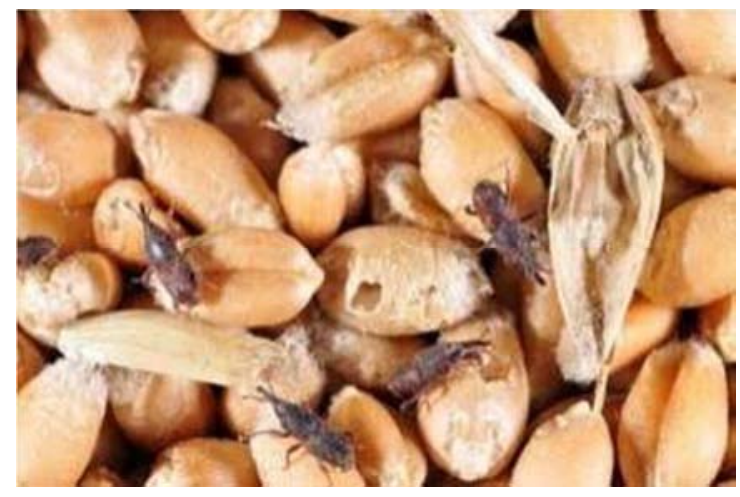

Figure 10. Infested wheat.

\section{vi. Immature Grains}

Wheat kernels which are distinctly green in color this were due to immature wheat kernel shown in figure 11 .

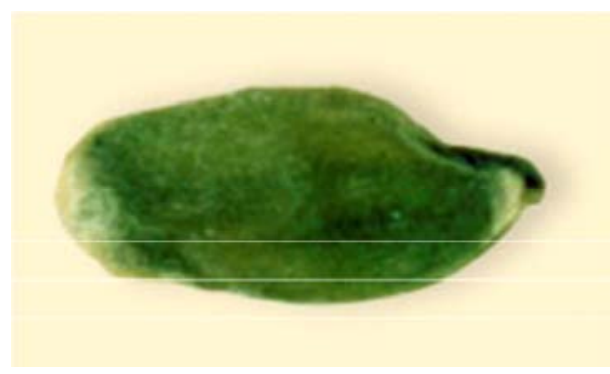

Figure 11. Immature wheat kernel. vii. Heat Damaged Wheat

Kernels damaged by external heat or as a result of fermentation were shown in figure 12 .

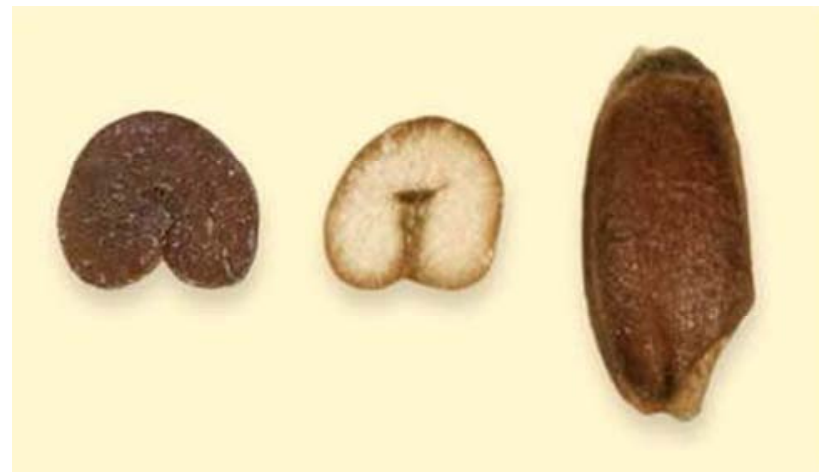

Figure 12. Heat damaged wheat kernel.

viii. Diseased Weather Damaged

Kernels with at least $1 / 3$ of the surface physically damaged or moldy due to weather conditions. The Diseased weather damaged kernels were illustrated in figure 13 .

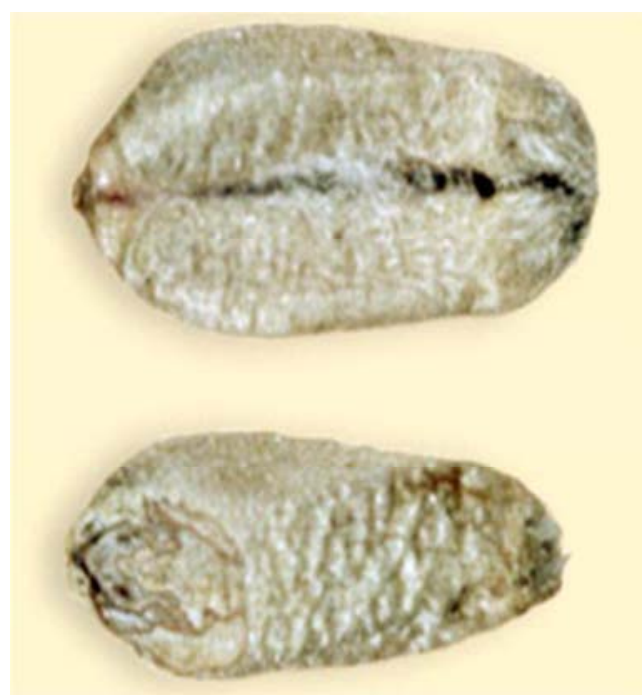

Figure 13. Diseased weather damaged kernels.

ix. Wheat Screenings

Small undersized wheat kernels that are retained on the 1.6 $\mathrm{mm}$ slotted sieve but pass through a $2.0 \mathrm{~mm}$ slotted sieve. The Wheat screenings were shown to left side in figure 14.

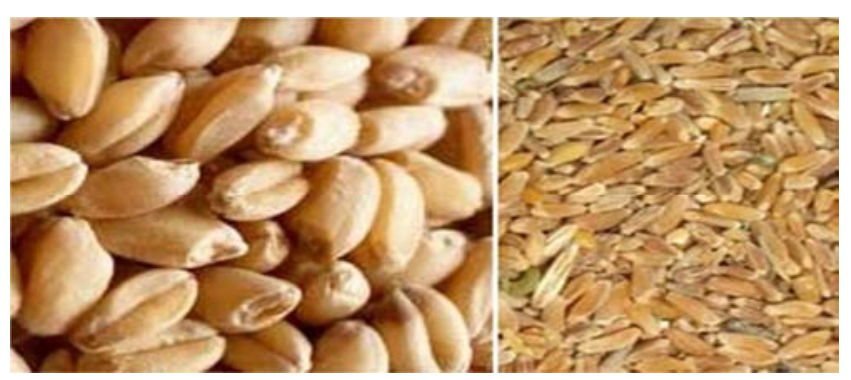

Figure 14. Wheat screenings (left).

x. Toxic and Noxious Weed Seeds 
Toxic and noxious weed seeds are those Seeds of weeds that are harmful or injurious to human or animal health i.e., Datura, corn-cockle, corn-vetch, ergor, crotalaria, darnel, castor-oil and treasel.

\subsection{Standard Requirements}

\subsubsection{Wheat Specifications Table (Grades)}

Wheat grains are classified as: Grade 1; Grade 2; Grade 3 or; Grade 4 according to the limits indicated in the table 3 , this were based on the quality test of Moisture Content, Standard of quality, Protein quality/content, percentage of Foreign Matter, Screenings percent, percentage of Unmillable material above the screen, Falling numbers, Wheat of other classes or Varieties, Edible grains other than wheat (whole or Identifiably broken), Total defective grains, Total Aflatoxins and Fumonisin which was determined by their respective standard method of tests.

Table 3. Wheat grades.

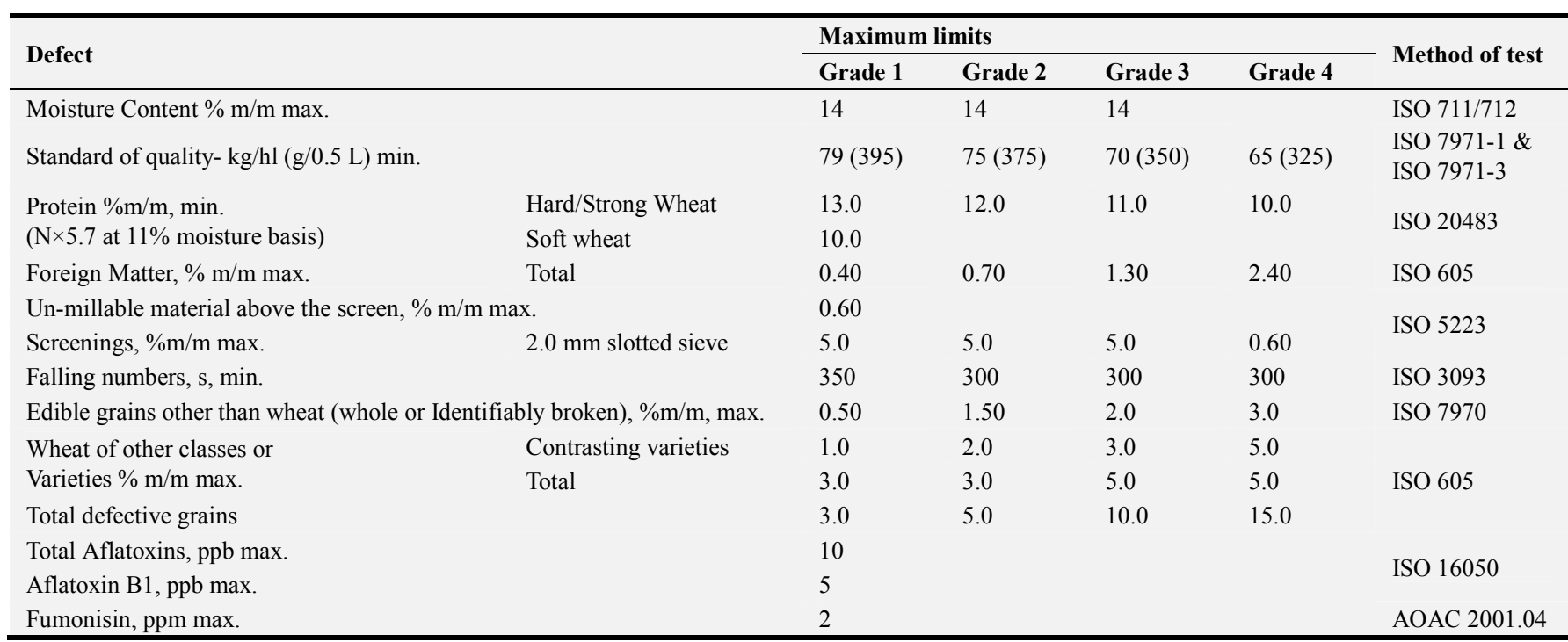

\subsubsection{Determination of Grades (Grading)}

i. Non-standard Test Method (Subjective Tests)

Formal grading methods are not always practical in the field. This is because the farmers or traders may lack the equipment needed to grade the grain based on Standard Test methods. The tests below are useful for getting a rough estimate of the grade of Wheat. Some of the tests are known to give results that are above those of the standard test method while others lower. Official results should be those that have been reached using Standard Test Methods.

Determination of Wheat defects using the count method

The ES 665: 2017 recommends this method to determine wheat defects. Wheat could be graded using the procedure below. For example, when grading for germinated grains: Take a representative sample of the Wheat to be evaluated.

a. Use the quartering method to subdivide the Wheat down to about 100 grains.

b. Use a $1.6 \mathrm{~mm}$ sieve to remove broken grains and foreign matter.

c. Handpick all foreign matter retained on the $1.6 \mathrm{~mm}$ sieve.

d. Count the number of wheat grains retained on the sieve (count 1)

e. Select all germinated grains and count them (count 2)

f. Express the percentage of germinated wheat as:

$$
\frac{\text { count } 2}{\text { Count } 1} \times 100
$$

All wheat defects including, pest damaged, weather damaged, shriveled, discolored, heat damaged, etc. can be estimated using this method. However, huge variances can be expected as compared to use of weight methods $(\% \mathrm{~m} / \mathrm{m})$.

Other quality parameters e.g. Broken grain, moisture content, screenings, protein content, falling numbers, bushel weight, and mycotoxins, cannot be determined without use of equipment.

Determination of Moisture Content

In the field, most farmers do not have moisture meters or a grading laboratory facility. Non-standard tests can be used to estimate the dryness of Wheat. To do this:

Method 1

a. Pick 10 grains at random.

b. Crush each grain between the teeth.

c. A reasonably dry grain will crush without leaving a pasty feel in the mouth.

Method 2

a. Select a random sample of wheat.

b. Fill a glass half-way with the wheat sample (the glass must be dry).

c. Add 2 teaspoons of dried salt (the salt should be previously dried in a pan over a fire for 15 minutes).

d. Shake the mixture for 2 minutes.

e. Leave to settle for 20 minutes.

f. Pour out the mixture.

g. Check for any salt clin ging on the walls of the glass.

$\mathrm{h}$. If any salt is found on the walls of the glass, then 
moisture content is greater than 14\%.

ii. Standard Test Methods

Visual and Organoleptic Test

Tests using senses of sight, smell and taste. Wheat for human and animal consumption should be free from foreign odors, moulds, live insects, rat droppings, toxic or noxious weed seeds and other hazardous contaminants. To check for this, the grain analyst needs to obtain a representative sample of the grain. Then $\mathrm{s}$ /he will use the senses of sight and smell to check the existence of these defects. This test is normally the first to be done. Other tests will follow if the wheat passes this test. This test can easily be conducted in the field because it does not require any equipment.

Testing for Foreign Odor

a. General test for foreign odor

b. Obtain a representative sample

c. Spread out the sample on a flat surface and smell it.

d. If no odor is detected, return the sample into the container and seal it.

e. Leave the sealed container for 24 hours and re-examine the sample.

f. The smell should be typical of Wheat without other smells e.g. chemicals, moldiness', earthy, rotten, musty smell, etc.

Rapid Test for foreign odor

a. Obtain a representative sample

b. Put a small quantity of ground or un-ground wheat kernels in a container

c. Pour some warm water $\left(60-70{ }^{\circ} \mathrm{C}\right)$ into the wheat and cover the container

d. After 2-3 minutes, decant the water and note whether foreign odor is present. Any grain with objectionable odor should be rejected.

Testing for Presence of Visible Infestation

a. Obtain a representative sample

b. Spread about 100 grams of the sample on a warm plate (at $40{ }^{\circ} \mathrm{C}$ ).

c. Cover the plate with a glass jar (bell glass jar if possible) to prevent the insects from escaping

d. After 15 minutes, sieve the grain through an appropriate sieve, e.g. $1.6 \mathrm{~mm}$ slotted sieve

e. Check for living insects, dead insects and insect larvae.

f. Using a scalped, cut across wheat kernels that are insect damaged, to check for live or dead insect (primary pests) harbouring in the grain.

g. Note the presence of rodent droppings.

h. Reject the grain of it has one or more live insects.

Determination of Moisture Content

ES 665: 2017 requires that the moisture content of clean, dry wheat should not exceed $14 \% \mathrm{~m} / \mathrm{m}$ determined by representative samples in accordance with ISO 711 and ISO 712. However, this requires expensive equipment, including a grinding mill and a constant-temperature oven electrically heated. In the field, moisture meters can be used for the estimation of moisture content. To determine moisture content using moisture meters, follow the manufacturer's instructions. Ensure that the moisture meters are maintained and calibrated often so as to get accurate results. Calibration of moisture meters is done by National Metrology institute. The Moisture meters were shown in figure 15.
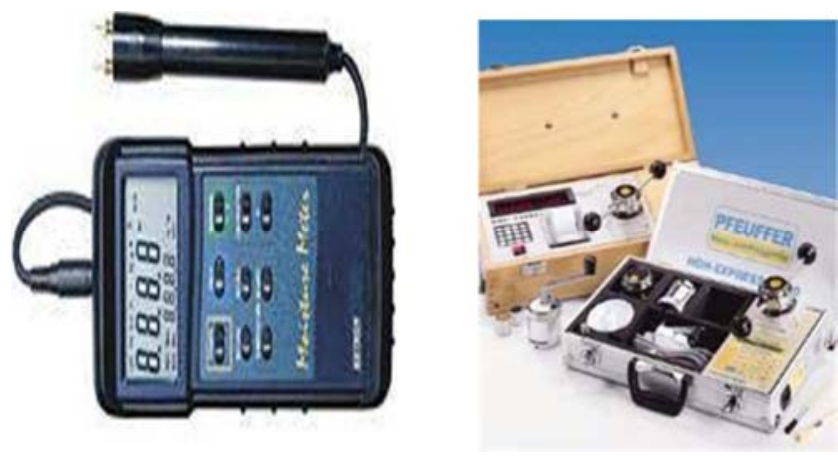

Figure 15. Moisture meters.

Determination of Foreign Matter

a. Place a clean dry basin (Bottom Pan) in place to receive any materials that may go through the sieve

b. Weigh 200 grams of the representative sample (weight 1)

c. Put the Wheat in the sieve provided $(1.6 \mathrm{~mm}$ slottedhole sieve).

d. Shake the sieve horizontally for 30 times for about 15 seconds.

e. Collect all the foreign organic matter that has passed through the sieve.

f. Weigh all the foreign matter

Collected from the bottom (weight 2)

$$
\text { Foreign matter }=\frac{\text { weight } 2}{\text { Weight } 1} \times 100
$$

Determination of Un-millable material above the sieve

These are foreign materials retained on top of the $1.6 \mathrm{~mm}$ slotted sieve after removal of foreign matter and broken grain.

a. From the sample retained on top of the sieve in 5.2.5 above (weight 1)

b. Handpick all un-millable foreign matter retained on top of the $1.6 \mathrm{~mm}$ slotted sieve.

c. Weigh the matter un-millable matter (weight 2)

d. Express the results as a percentage

Un - millable matter above the screen $=\frac{\text { weight } 2}{\text { Weight } 1} \times 100$

Determination of Broken Grains

a. From the working sample weighed in 5.2.5 above (weight 1)

b. Collect all the whole and broken grains that passed through the $1.6 \mathrm{~mm}$ slotted-hole sieve.

c. Weigh the broken grain (weight 2)

d. Express the percentage of broken Wheat as follows:

$$
\text { Broken Grain }=\frac{\text { weight } 2}{\text { Weight } 1} \times 100
$$

Filth 
a. From the working sample weighed in 5.2 .5 above (200 grams) (weight 1)

b. Collect all the filth that went through the sieve and that which remains on top.

c. Weigh the filth (weight 2)

d. Estimate the percentage filth level as:

$$
\text { Filth }=\frac{\text { weight } 2}{\text { Weight } 1} \times 100
$$

Determination of defective grains

a. Obtain a representative sample.

b. Mix and subdivide the sample using a sample divider or the quartering method to obtain a working sample of 25 $\mathrm{g}$ (weight 1).

c. Use the $1.6 \mathrm{~mm}$ slotted sieve to remove foreign matter and broken grains.

d. Pour the wheat retained on the sieve on a bench.

e. Pick defective grains (pest damaged, discolored, germinated, immature, heat damaged, diseased weather damaged, frost damaged and shriveled wheat kernels)

f. Weigh all defective grains picked (weight 2)

g. Express the percentage defective grains as:

$$
\text { Defective grains }=\frac{\text { weight } 2}{\text { Weight } 1} \times 100
$$

Total Defective Grains

This refers to all defects mentioned above.

a. From the working sample weighed in 5.2.5 above (200 grams) (Weight 1)

b. Collect the Wheat grains retained by the sieve

c. Pour them on a bench

d. Pick all defective grains by hand (diseased, discolored, stained, immature/shrivelled, pest damaged, etc.)

e. Weigh the defective wheat kernels (Weight 2)

f. Express the percentage total defective grains as:

$$
\text { Total defective grains }=\frac{\text { weight } 2}{\text { Weight } 1} \times 100
$$

Assessment of Contrasting Varieties

This involves picking out all grains with contrasting kernel characteristics including the color, shape and length of the kernel, shape of the germ, crease and brush, figure 16 .

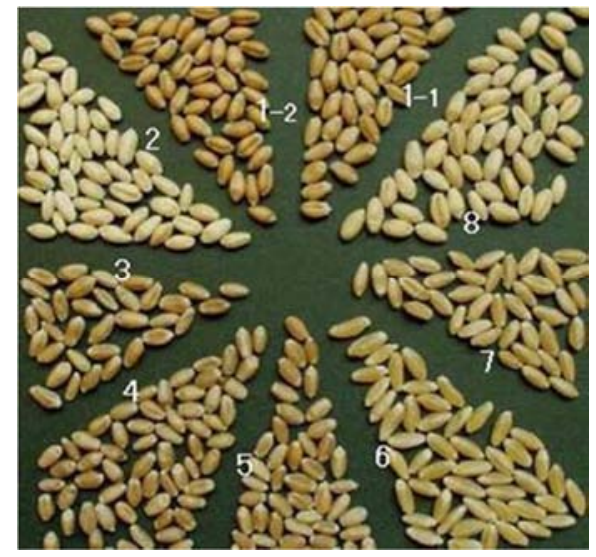

Figure 16. Contrasting wheat varieties.

\section{Determination of Bulk density}

Determination of bulk density should be done in accordance to ISO 7971-1 and ISO 7971-3. There are several equipment for determining bulk density. Most come with instructions which have to be followed strictly. The laboratory equipment measuring bulk density and Hectoliter test weight figures 17 and 18 .

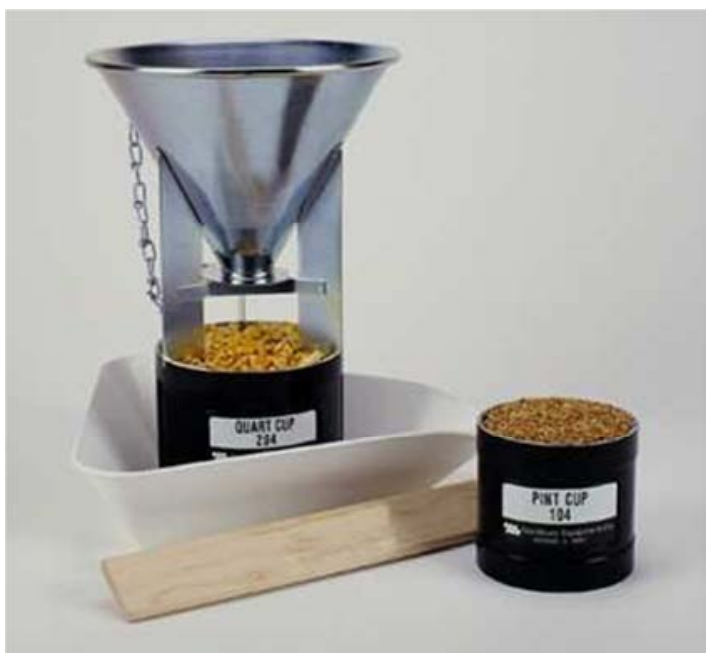

Figure 17. Measuring cup and cox funnel for bulk density.

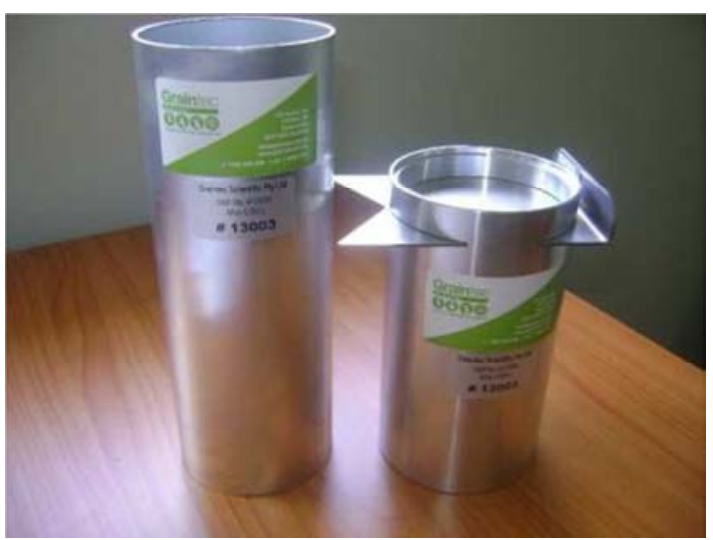

Figure 18. Hectoliter test weight kit.

The common field method for determination of bulk density generally involves weighing grain that occupies a $0.5 \mathrm{~L}$ measuring cup. The process is as follows: Clean the grain using the $1.6 \mathrm{~mm}$ slotted sieve (foreign matter affects bulk density)

a. Place a cox funnel, with its outlet shut, on top of the $0.5 \mathrm{~L}$ cup

b. Pour the grain into the cox funnel using a suitable scoop.

c. Open the cox funnel slide and fill the $0.5 \mathrm{~L}$ cup until it overflows.

d. Remove the funnel from the $0.5 \mathrm{~L}$ cup.

e. Sweep the top of the cup using a suitable stick to remove excess grain in a light semi- circular motion.

f. Transfer the contents of the $0.5 \mathrm{~L}$ cup into the pan of a weighing pan and weigh the grain to the nearest $5 \mathrm{~g}$.

Determination of Protein content 
Determination of protein content is done in accordance with ISO 20483 which uses the Kjeldahl method as the reference method. This involves decomposing the grain sample using sulphuric acid, to remove ammonium sulphate. This is followed by distilling the sample using sodium hydroxide to convert ammonium sulphate to ammonia, the determining the amount of ammonia (hence nitrogen) by back titration. In practice, this analysis is largely automated. In the field, it is possible to use equipment that employs infra-red technology to estimate protein content.

Determination of falling numbers

Determination of falling numbers is done in accordance with ISO 3093. Falling numbers is an indicator of the extent of sprouting of wheat figure 19. Wheat germination released enzymes that cause digestion of the endosperm (starch). This test required specialized equipment. The basis of the test is to measure the time it takes for a stirrer to fall through gelatinized slurry in a test tube, made from flour of the wheat sample. Falling number: affects absorption, dough handling, fermentation; use to determine malting quality and age and lso use to estimate formula, mix time, proof time.
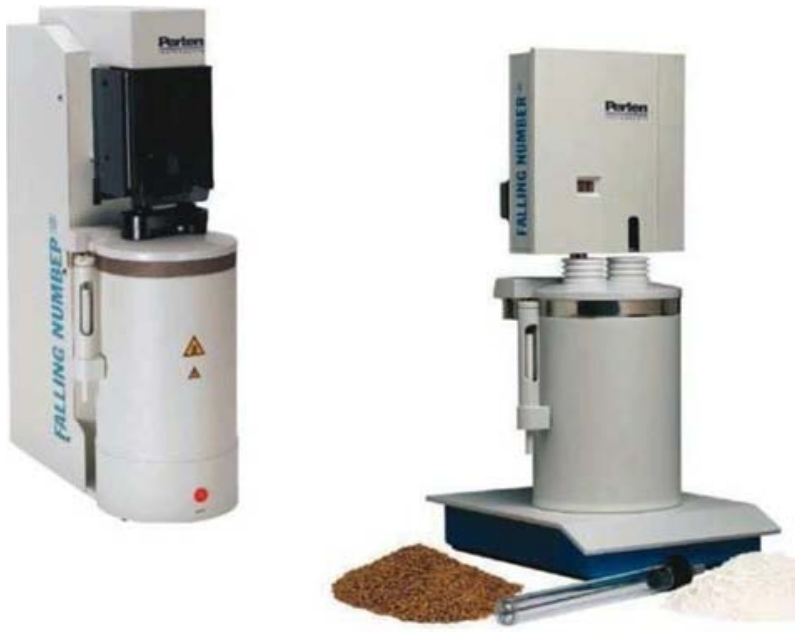

Figure 19. Falling number machine.

Determination of Mycotoxins

The mycotoxin deoxynivalenol (DON) is a metabolite produced by several Fusarium genuses. Also known as vomitoxin, DON belongs to trichotecenes chemical family: sesquiterpenes with 12, 13-epoxy group. Recent studies demonstrated that DON is commonly found at high levels in cereals intended for human and animal consumption [38]. In addition many studies have shown substantial adverse effects of DON on animal and human health. Even at low levels, deoxynivalenol may cause feeding refuse and at higher levels induce vomiting.

Mycotoxins are a group of chemicals produced by certain mould fungi. This broad category includes Aflatoxins and Fumonisin. These fungi, Aspergillus flavus and Aspergillus parasiticus, can be recognized by their yellow-green or greygreen, or pink colours. Aflatoxin mycotoxins are toxic to humans and even more toxic to animals. They also cause cancer in humans and animals. The presence of Aflatoxin is tested using thin layer chromatography, high performance liquid chromatography or absorbance meters (e.g. Elisa readers), rapid test kits and Black light. Aflatoxin may be found in good looking grain. Mouldy wheat does not necessarily have high Aflatoxin levels. It could contain other mycotoxins though. Representative samples have to be taken to a laboratory capable of testing for Aflatoxin. The results should not exceed $10 \mathrm{ppb}$ of total Aflatoxins and $5 \mathrm{ppb}$ for Aflatoxin B1. For Fumonisin, the results should not exceed 2 ppb for any of the four grades; figure 20.
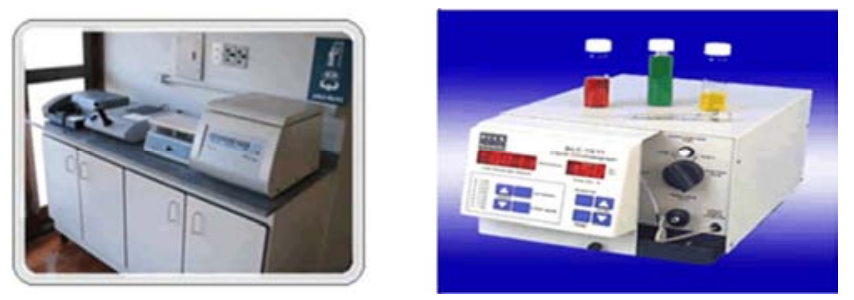

Figure 20. Elisa kit with High Performance Liquid Chromatography Unit.

\section{Contaminants}

Wheat plays a vital role in human growth by providing carbohydrates, proteins and certain inorganic micronutrients [39]. Consumption of grain is safe when accumulation of metals is under the permissible lim-its [40, 41]. However, when accumula-tions exceed the permissible limit, it exerts toxic effects andmay produce a variety of diseases in human [42-44]. Wheat must be free of heavy metals in amounts stipulated by the Codex Alimentarius Commission. Heavy metal quantities can be determined by testing in a laboratory using a spectrophotometer figure 21 and the contaminant limits are shown in Table 4.

Table 4. The contamination limit of heavy metals in wheat.

\begin{tabular}{ll}
\hline Heavy metal & contaminant limits \\
\hline Arsenic & $0.1 \mathrm{mg} / \mathrm{Kg}$ \\
Cadmium & $0.1 \mathrm{mg} / \mathrm{Kg}$ \\
Lead & $0.2 \mathrm{mg} / \mathrm{Kg}$ \\
Mercury & $0.1 \mathrm{mg} / \mathrm{Kg}$ \\
Tin & $0.1 \mathrm{mg} / \mathrm{Kg}$ \\
\hline
\end{tabular}

$\mathrm{Mg} / \mathrm{Kg}$ is equivalent to ppm (parts per million).

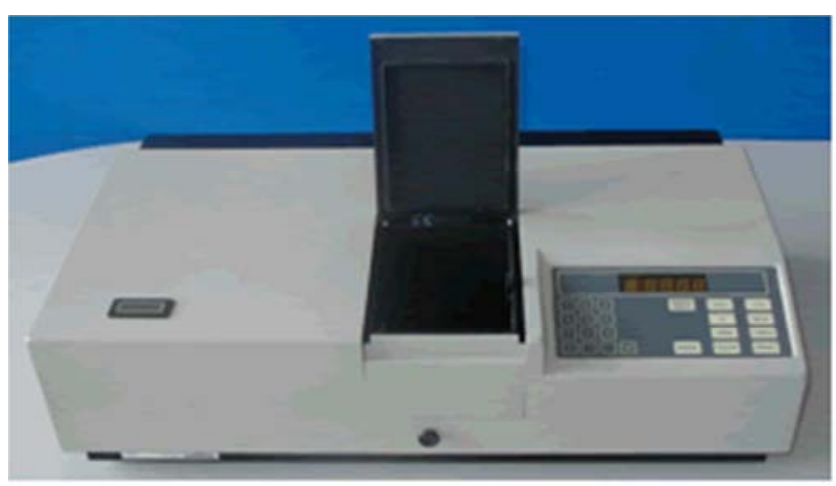

Figure 21. Spectrophotometer.

\subsection{Hygiene}

The product covered by the provisions of the ES 665: 2017 
Standard shall be prepared, packed, stored, transported and distributed under hygienic conditions. This implies that maximum care must be taken to ensure that wheat is packaged in clean containers by clean people. The areas that the Wheat is stored should be clean and meet hygiene standards. These stores should be free from pests (e.g. rodents, cockroaches, weevils and other vermin). Modes of transport should also be clean; when tested by appropriate methods of sampling and examination, the wheat shall be free from pathogenic microorganisms, substances originating from micro-organisms, or other poisonous or deleterious substances in amounts which may constitute a health hazard. Pathogenic micro-organisms are minute living microbes that may cause diseases commonly referred to as germs, this include harmful bacteria, yeasts and moulds. A quick test for these harmful bacteria is done by determining the presence of coliforms. This is done by incubating a weighed sample in specific media at a specified temperature for a period of 48 hours. It is not feasible to do this test in the field.

\subsection{Packaging}

The following information shall be provided in order to comply with the requirements of ES 665: 2017

Wheat, when not handled in bulk, shall be packed in new bags (maximum $50 \mathrm{~kg}$ net weight) or similar acceptable protective containers which will safeguard the hygienic and other qualities of the wheat. In Ethiopia it is common practice to package wheat in second- hand bags. For a wheat consignment to comply with the requirements of ES 665: 2017, new bags must be used. The containers including packaging material shall be made only of substances which are safe and suitable for the intended use. These materials should be food grade and in the event of need for verification, a certificate from the supplier should be available to demonstrate that the materials have been declared for use in foods and foodstuff

\section{Conclusion}

A good wheat variety must meet the needs of all in the wheat value chain. That is, from the farmer, to the miller, to processors and manufacturers through to the consumer. Wheat breeders need to understand the needs of all in the value chain and use the available genetics and quality testing capability to develop new varieties that will produce the high quality, attractive and nutritious bread, cake and pastry products demanded by consumers. Successful wheat breeding is about having clearly defined and achievable targets. Agronomic attributes like plant height, straw strength, ease of threshing and maturity optimum for the target production region are essential components of all varieties. A thorough knowledge of the environment of the target production region is critical, as this determines yield potential, the range and type of challenges the crop will experience from biological threats such as pests and diseases and soil and environmental stresses. Major quality parameters in contract farming agreement were includes, Impurity (6-15\%), Moisture content $(12 \%$ of maximum), Protein (9\% of minimum) and Hectoliter weight $(76 \mathrm{~kg} / \mathrm{hl})$. Impurity Occur due to poor post-harvest practice; wheat with high impurity will decrease flour yield and machine ability. Impurities which have an impact on human safety will not be accepted. The higher Moisture content tends to Short shelf life Favorable for fungal and mould growth which will be harmful for human consumption less flour yield. Protein quality and quantity were one of the major flour and grain quality determinant factors of wheat quality. The major factor influencing protein quantity and quality are: (a) Nitrogen and sulphur influence on proteins. Fertilization and site: the total protein, protein unit and subunit contents increased with the supply of nitrogen to grain. (b) bug damage and (c) Soil temperature; Moderately high soil temperature during grain filling stimulate nitrogen uptake from the soil and nitrogen retrains location from the vegetative parts to the grain Low protein or/and weak protein will influence the flour quality and affect product quality (biscuit, bread and pasta). Those $1 \%$ increase in protein will have $1.3 \%$ increase in water absorption. Hectoliter weight Influenced by environmental condition and bug damage this will reduce the yield of wheat. High shriveled, sprouted and pest damaged wheat will have low Hectoliter weight while low Hectoliter weight indicates less extraction rate.

Glossary of commonly-used Wheat grain (cereals) quality terms

Soft wheat: a soft, opaque and less compact endosperm compared to hard wheat. Soft wheat is generally considered more suitable for the production of cake and biscuit flours.

Sprouted grain: grain which has begun to germinate, resulting in increased levels of the enzyme $\alpha$-amylase. This results in a softening of the grain, reducing its milling value and end-product quality.

Starch damage: mechanical damage to starch granules as a result of milling. Damaged starch granules are more susceptible to enzyme attack and have an increased level of water absorption.

Test weight: is the weight of a specific volume of grain and is usually determined using a Schopper chondrometer calibrated as kilogram/ hectolitre $(\mathrm{kg} / \mathrm{hl})$. Test weight is used by the grain trade as an indication of milling potential of a parcel of wheat.

Gluten: the elastic protein acetous material that remains after the water solubles and starch are washed out of dough. Gluten content of flour is a measure of bread making quality.

Grade: a is used in variety classification to describe the quality of wheat varieties that have been classified according to processing criteria, end-use potential, and relative market value into one of the major marketing classes.

Grist: the blend of wheat that is made up in the mill to produce a specific flour.

Hard wheat: wheat which has a vitreous endosperm generally considered an advantage for the production of Bread making flours.

Mixograph: a recording dough mixer used for evaluating the dough mixing properties of a wheat flour. It measures and records the resistance of dough during mixing. 
Near Infrared Region: is defined as the part of the infrared spectrum lying closest to visible light, that is, that part of the electromagnetic spectrum in the wavelength range 750 to $2600 \mathrm{~nm}$.

Physical dough tests: flour quality tests based on the measurement of some physical dough property such as elasticity, viscosity and resistance to extension.

RVA (Rapid Visco Analyser): a rotational viscometer that continuously records the viscosity of a slurry under controlled temperature conditions. Is able to operate under varied temperature and shear conditions.

Screenings: the amount of small, cracked or broken grains and small foreign seeds that pass through a sieve or screen.

$1,000 /$ kernel weight: is the weight of 1,000 kernels of grain. It is a measure of grain size and density and is used as an indicator of the milling potential of wheat.

Unmillable material: where whiteheads, chaff and light foreign seeds remain on top of a $2 \mathrm{~mm}$ sieve after the screening process.

Viscograph (or Amylograph): a recording viscometer that measures the viscosity of aqueous slurry of starch or flour as it is heated through a predetermined cycle. The viscosity is measured by the resistance that the heating slurry offers to a mixing paddle or pins.

Water absorption: the amount of water, expressed as percentage of flour weight that is required to produce a workable dough.

Yellow pigment content: a measure of the naturally occurring xanthophyll pigments in flour.

Flour paste viscosity: maximum viscosity during the heating phase of an Rapid Visco Analyser or Viscograph. Flour paste viscosity tests strongly reflect the pasting properties of the major component, starch, but also other components, including arabinoxylans and protein. Paste viscosity tests on flour, particularly the measurement of peak viscosity, are very sensitive to the effects of the starch degrading enzyme $\alpha$-amylase, which is often associated with rain damage to the grain.

Alveograph: a dough testing instrument that measures the resistance to deformation and extensibility of a clamped discshaped piece of dough by forming a bubble using air pressure applied from below the dough piece. It is used to assess the potential end-use quality of a flour.

Baking absorption: the amount of water, expressed as a percentage of flour weight, that must be added to make a dough for a specific baked product.

Baking quality: the ability of a wheat flour to produce a particular type of baked product.

Buckiness: a term used in the baking industry to describe dough that resist extension and are too tough for proper handling.

Classification: the term used to describe the process by which wheat varieties are categorized.

Conditioning (tempering): the controlled wetting of grain followed by a resting period during which the added water toughens the bran and mellows the endosperm in preparation for milling.
Colour stability: The difference in lightness (brightness) values of a noodle sample measured over a specific time (usually 24 hours).

Dockage: the amount of unmillable or foreign material in a grain sample, which may readily be removed by mechanical means.

Dough development time: a measure of the time needed to develop dough to a standard consistency. This is known as Farinograph development time.

Dough stability: a measure of dough strength using the Farinograph. It is the time that the dough maintains maximum consistency. It sometimes refers to the ability of the dough to tolerate under and over mixing.

Extensibility: the physical property of solid or semi-solid substances to stretch or increase in size. In Australia it is typically measured using an Extensograph. Dough extensibility is an important criterion for bread making quality.

Extensograph: an instrument that is used for measuring the extensibility and resistance to extension of a wheat flour dough mixed under standard conditions.

Falling Number (or Hagberg) test: a test to assess the soundness (freedom from sprouting and $\alpha$-amylase) of grain.

Farinograph: an instrument that mixes flour and water into a dough and produces a record of the resistance that the dough offers to the mixing blades. Used in the evaluation of the bread making quality of flour.

Farinograph water absorption: the percentage of water, expressed on a flour weight basis, required to develop the dough to a standard consistency.

Flour ash: the amount of mineral matter, usually expressed in $\%$, and is determined by incinerating a weighed amount of flour and weighing the residue. Flour ash is an indicator of flour purity, indicating the level of bran and non-endosperm contamination in the flour.

CIE: Commission Internationale de L'Eclairage.

Flour colour:

CIE L*: indicates the lightness in CIE colour space and is commonly referred to as brightness

$\mathrm{CIE} \mathrm{a}^{*}$ : indicates the value of red/green hue in CIE colour space

CIE $b^{*}$ : indicates the value of the yellow/blue hue in CIE colour space

Kent Jones colour grade: is a reflectance measurement taken on a flour-water slurry and values are indicative of flour brightness and bran contamination.

Gelatinization: irreversible swelling of starch granules followed by formation of a viscous gel when starch is heated in excess water.

\section{References}

[1] FAO. 2016. World Food Situation- Food Cereal Supply and Demand Brief. United Nations Food and Agriculture Organization, Rome. Government of Pakistan. 2009. Economic Survey. Economic Affairs Division, Ministry of Finance, Islamabad, Pakistan. 
[2] Ethiopian standard agency 665: 2017. Wheat grain specification, second edition.

[3] Birdsall, "Summary and Areas for Future Research." Am. J. of Clin. Nutr. 41 (5 suppl) May 1985: 1172-1176.

[4] FAO (Food and Agriculture Organization of the United Nations). 2005. FAOSTAT [Online]. Available at http://www.fao.org/faostat [cited 24 Feb. 2005; verified 14 Oct. 2005].

[5] Slafer, G. A. and E. H. Satorre, 1999. An introduction to the physiological - ecological analysis of wheat yield. In E. H. Satorre and G. A. Slafer (Eds.), Wheat: Ecology and physiology of yield determination, 3-12.

[6] CSA. 2015. Agricultural Sample Survey. Report on Area and Production of Major Crops for Private Peasant Holdings, 2014/15 Meher Season. Central Statistical Agency, Addis Ababa.

[7] CSA, 2007. Agricultural sample survey: Report on area and production for major crops. Statistical Bulletin 388. Addis Ababa, Ethiopia.

[8] Kent NL and AD Evers. 1994. Technology of Cereals. 4th Edn, Pergamon Press, Oxford, UK.

[9] CIMMYT, 2000.1998/99. World Wheat Facts and Trends. Global Wheat Research in a Changing World, Challenges and Achievements, CIMMYT, D. F, Mexico.

[10] FAO (Food and Agriculture Organization of the United Nations). 1994. FAO Year book production 1993. Vol. 47. Rome, Italy.

[11] Schulthess, U., B. Feil and S. C. Jutzi. 1997. Yield independent variation in grain nitrogen and phoshororus concentration among Ethiopian wheat. Agronomy Journal. 89 (3): 497-506.

[12] Bekeke Hunde Kotu, H. Varkuijl, W. Mwangi and D. G. Tanner, 2000. Adaptation of improved wheat technologies in Adaba and Dodola woredas of the Bale highlands, Ethiopia. Mexico D. F: International Maize and Wheat Improvement Centre (CIMMYT) and Ethiopian Agricultural Research Organization (EARO).

[13] Kaplinsky, R. and Morris, M. 2000. A Handbook for Value Chain Research. IDRC, Ottawa, Canada.

[14] Schmitz, H. 2005. Value Chain Analysis for Policy-Makers and Practitioners. International Labour Organization.

[15] Anandajayasekeram, P. and Berhanu Gebremedhin. 2009. Integrating Innovation Systems Perspective and Value Chain Analysis an Agricultural Research for Development: Improving Productivity and Market Success (IPMS) of Ethiopian Farmers Project, Working Paper 16. ILRI, Nairobi, Kenya.

[16] Beamon, B. M. 1998. Supply chain design and analysis: Models and methods. International Journal of Production Economics, 55 (3): 281-294.

[17] KIT, MaLi, F. and IIRR, 2006. Chain empowerment: Supporting African farmers to develop market. Hand book Royal Tropical Institute, Amsterdam; Faida Markrt Link, Arusha; and International Institute of Rural Reconstruction, Nairobi.

[18] Kaplinsky, R. and Morris, M. 2001. A Handbook of Value Chain Analysis. Working paper prepared for the IDRC,
Institute for Development Studies, Brighton, UK.

[19] GTZ (German Technical Cooperation). 2007. Value Links Manual -The Methodology of Value Chain Promotion, 1 st Edition. Eschborn, Germany. 45p.

[20] Fleming, K. 2005. Value-added strategies: Taking agricultural products to the next level. Honolulu (HI): University of Hawaii. Agribusiness, 31 (4): 125-134.

[21] Berhanu Gebremedhin and Moti Jaleta. 2010 Commercialization of smallholders: Does market orientation translate into market participation? Improving productivity and market success (IPMS) of Ethiopia farmer project, working paper 22. ILRI, Nairobi, Kenya.

[22] Backman, T. N. and Davidson, W. R. 1962. Marketing Principle. The Ronal Presses Co., New York. pp. 3-24.

[23] Kotler, P. and Armstrong, G. 2003. Principle of Marketing, 10th Edition. Hall of India Pvt. Ltd. New Delhi, pp 5-12.

[24] Abbott, C. and Makeham, P. 1990. Agricultural Economics and Marketing in the Tropics, 2nd Edition. Longman Group Limited. Harlow, England.

[25] CIAT (International Center for Tropical Agriculture). 2004. Increasing the Competitiveness of Market chains for Smallholder producers. Manual 3: Territorial Approach to Rural Agro-Enterprise Development Project. Cali, Colombia.

[26] Thakur, D. S., Harbans, L., Thakur, D. R., Sharma, K. D. and Saini, A. S. 1997. Market supply response and marketing problems of farmers in the Hills, Indian Journal of Agricultural Economics, 52 (1): 139-150.

[27] Islam, M. S., Miah, H. and Haque, M. M. 2000. Marketing system of marine fish in Bangladesh: Bangladesh Journal of Agricultural Economics, 24 (2) 127-142.

[28] Wang XY, He MR, Li F, Liu YH, Zhang HH, Liu CG (2008c) Coupling effects of irrigation and nitrogen fertilization on grain protein and starch quality of strong-gluten winter wheat. Front Agric China 2: 274-280.

[29] Zhang Y, He ZH, Ye GY, Zhang AM, Ginkel MV (2004b) Effect of environment and genotype on bread-making quality of spring-sown spring wheat cultivars in China. Euphytica 139: $75-83$.

[30] He ZH, Yang J, Zhang Y, Quail KJ, Peña RJ (2004) Pan bread and dry white Chinese noodle quality in Chinese winter wheats. Euphytica 139: 257-267.

[31] Li HN, Zhang YL, Wu XQ, Li ZZ (1995) Determination and evaluation on the main quality characters of wheat germplasm resources in China. Sci Agric Sin 28: 29-37 (in Chinese with English abstract).

[32] Jing Q, Jiang D, Dai TB, Cao WX (2003) Effects of genotype and environment on wheat grain quality and protein components. Chinese J Appl Ecol 14: 1649-1653.

[33] Peterson CJ, Graybosch RA, Shelton DR, Baenziger PS (1998) Baking quality of hard winter wheat: response of cultivars to environment in the Great Plains. Euphytica 100: 157-62.

[34] Zhao L, Zhang KP, Liu B, Deng ZY, Qu HL, Tian JC (2010) A comparison of grain protein content QTLs and flour protein content QTLs across environments in cultivated wheat. Euphytica 174: 325-335. 
[35] Shi SB, Ma L, Shi QH, Liu X, Chen LM, Liu JX, Wang ZL (2005) Effect of nitrogen application timing on protein constitutes and its dynamic change in wheat grain. Plant Nutr Fert Sci 11: 456-460.

[36] Weegels PL, Hamer RJ, Schofield JD (1996) Functional properties of wheat glutenin. J Cereal Sci 23: 1-18.

[37] Moss, 1973. Understanding Australian Wheat Quality.

[38] CAHILL (L. M.), KRUGER (S. C.), MCALICE (B. T.), RAMSEY (C. S.), PRIOLI (R.), KHON (B.), 1999. Quantification of deoxynivalenol in wheat using immunoaffinity column and liquid chromatography. J. Cromatogr. 859: 23-28.

[39] Anita, S., Rajesh, K. S., Madhoolika, A., Fiona, M. M., 2010. Healthrisk assessment of heavy metals via dietary intake of foodstuffsfrom the wastewater irrigated site of a dry tropical area of India. Food Chem. Toxicol. 48, 611-619.
[40] Das, A. K., 1990. Metal Ion Induced Toxicity and Detoxification byChelation Therapy, A textbook on Medical Aspects of Bio-inorganic chemistry. CBS, Delhi, 17-58.

[41] Khan, S., Cao, Q., Zheng, Y. M., Huang, Y. Z., Zhu, Y. G., 2008.

[42] Nariago, J. O., 1990. Global metal pollution poisoning the biosphere. Environment 32, 7-33.

[43] Melamed, R., Cao, X., Chen, M., Ma, L. Q., 2003. Field assessment oflead immobilization in a contaminated soil after phosphateapplication. Sci. Total Environ. 305, 117-127.

[44] AL-Othman, Z. A., Naushad, Mu., Khan, M. R., Wabaidur, S. M., 2012. A comparative study on characterization of aluminiumtungstate and surfactant based aluminum tungstate cation exchang-ers: analytical applications for the separation of toxic metal ions. J. Inorg. Organomet. Polym. 22, 352-359. 